Reprinted with permission from: Weed Technology, April-June 1990. 4(2):235-238.

Published and copyrighted by: Weed Science Society of America. http://www.wssa.net

\title{
Ropewick application of picloram for leafy spurge (Euphorbia esula) control ${ }^{1}$
}

\author{
RUSSELL S. MOOMAW and ALEX R. MARTIN \\ Prof., Dep. Agron., Univ. Nebr., Concord, NE 68728, and Lincoln, NE 68583, respectively.
}

\begin{abstract}
:
Picloram was applied to leafy spurge using flexible and rigid ropewick applicators for 3 years at each of two upland pasture sites. The ropewick applicators were a cost-effective way to apply picloram to control leafy spurge compared to broadcast application, but minimal advantage was demonstrated for the segmented, flexible unit compared to the rigid applicator. Picloram applied as an $80 \mathrm{~g}$ ae/L solution through ropewick applicators controlled leafy spurge equal to broadcast picloram at $1.1 \mathrm{~kg} / \mathrm{ha}$ while using $36 \%$ as much picloram.
\end{abstract}

Nomenclature:

Picloram, 4-amino3,5,6-trichloro-2-pyridinecarboxylic acid; leafy spurge, Euphorbia esula L. \#² EPHES.

\section{Introduction}

Leafy spurge is a major problem in the northcentral and northwestern states. Against this invader of range and pastures, researchers are investigating biological control with insects $(5,11)$, fungi $(2,5)$, and sheep (7); plants allelopathic against leafy spurge (8); cultural control (3); and refinements in chemical application techniques (11).

Picloram applied at $2.2 \mathrm{~kg} / \mathrm{ha}$ is the most consistently effective herbicide treatment available to control leafy spurge (4). However, high cost limits use of this treatment to

\footnotetext{
${ }^{1}$ Received for publication July 31, 1989, and in revised form Dec. 11, 1989. Published as J. Ser. Paper No. 8983, Nebr. Agric. Exp. Stn.

${ }^{2}$ Letters following this symbol are a \# WSSA-approved computer code from Composite List of Weeds, Revised 1989. Available from WSSA, 309 W. Clark St., Champaign IL 61820.
} 
small infestations. Cost-effective annual treatments, which increase forage yields include 2,4-D [(2,4dichlorophenoxy) acetic acid] at $1.7 \mathrm{~kg} / \mathrm{ha}, 2,4-\mathrm{D}$ plus dicamba (3,6-dichloro2-methoxybenzoic acid) at 1.1 plus $0.6 \mathrm{~kg} / \mathrm{ha}$ and 2,4-D plus picloram at 1.1 plus 0.3 $\mathrm{kg} / \mathrm{ha} \mathrm{(4).}$

Selective application equipment like the roller, modified pipewick, and ropewick reduce the amount of herbicide applied per hectare compared to broadcast application. Messersmith and Lym (9) found that picloram at concentrations of 30 to $60 \mathrm{~g} / \mathrm{L}$ dispensed with a roller applicator controlled leafy spurge similar to picloram broadcast at 1.1 to 2.2 $\mathrm{kg} / \mathrm{ha}$. The roller applied only $40 \%$ as much picloram as broadcast treatments of 2.2 $\mathrm{kg} / \mathrm{ha}$. Alley and Messersmith (1) reported that a modified, nonrope pipewick applicator dispensed 17 to $25 \%$-as much picloram as a broadcast application of $2.2 \mathrm{~kg} / \mathrm{ha}$.

Application of picloram with selective applicators may not reduce picloram soil residue. Messersmith and Lym (9) found that picloram residues in soil following roller application were similar to those from broadcast-applied picloram at 0.3 to $1.1 \mathrm{~kg} / \mathrm{ha}$. Detection of soil picloram residues following roller application was attributed to herbicide washing off the foliage, plant decomposition, and direct exudation from leafy spurge root tissue (9). Hickman et al. (6) quantified release of picloram from pipewick-treated leafy spurge plants. Picloram release from roots occurred rapidly with $86 \%$ of the total picloram detected in the 0 - to $13-\mathrm{cm}$ soil depth being there $1 \mathrm{wk}$ after treatment. Picloram release from roots was greatest from plants treated in the flowering and seed filling stage and increased with picloram concentration used.

Construction of a segmented, flexible ropewick applicator to facilitate application of herbicide solution on rolling terrain was described previously (10). The objective of this research was to evaluate leafy spurge control with picloram applied through flexible or rigid applicators and a broadcast application.

\section{Materials and methods}

Two upland, native grass pastures in northeast Nebraska with soil in the Moody-Nora (fine silty, mixed, mesic Udic Haplustolls) series were selected for the experiments. Experimental design was a randomized complete block with individual plots 4.6 by $19.8 \mathrm{~m}$ (Site 2) or $30 \mathrm{~m}$ (Site 1) with four replications. At Site 1, plots were treated in 1984, retreated in 1985 and 1986, and last evaluated in 1987. Site 2 was treated in 1985, retreated in 1986 and 1987, and last evaluated in 1988.

Site 1 had a uniform 13\% slope with a relatively smooth soil surface. Plots were established perpendicular to the topographic slope. At Site 2, some plots were laid out perpendicular to a $5 \%$ slope, while others were on moderate 3 to $5 \%$ slopes with an undulating soil surface. Treatments applied; were 24 and $80 \mathrm{~g} / \mathrm{L}(\mathrm{v} / \mathrm{v})$ solutions of picloram delivered through the flexible (10), or 4.6-m rigid ropewick applicators, in either one or two passes. With two passes, the applicator went back through the same plot, usually in the opposite direction of the first pass. In addition, an untreated control and a broadcast application of picloram at $1.1 \mathrm{~kg} / \mathrm{ha}$ were included. The broadcast picloram treatment was

Page 2 of 7 
applied in 190-L/ha spray solution with a tractor-mounted compressed-air-pressurized sprayer using 11002 nozzles $^{3}, 190 \mathrm{kPa}$ pressure at $2.9 \mathrm{~km} / \mathrm{h}$.

The rigid pipewick was constructed from $7.6-\mathrm{cm}$ diam polyvinyl chloride pipe. Two 2.3-m pipe lengths were connected with a collar to make a 4.6-m rigid, noncompartmentalized pipe. The pipe reservoir was filled to three-fourths capacity to minimize the adverse effect of solution shifting to the lower end of the pipe. The rigid ropewick generally was constructed according to Cooperative Extension Service guidelines ${ }^{4}$. Pistachio rope ${ }^{5}$, which has a diamond braid polyester outer covering and an acrylic core, was used in both applicators. Ropewicks were flushed with water between applications of the picloram solutions. After refilling, the new solution was allowed to drip for several minutes to remove water from the ropes.

Ropewick applicators were carried on a tractor-mounted, front-end loader operated at $5.0 \mathrm{~km} / \mathrm{h}$. The flexible ropewick applicator was carried on gauge wheels $15 \mathrm{~cm}$ above the soil surface. Thus, the top half of most leafy spurge plants, were wiped with picloram solution. The rigid ropewick was positioned 20 to $30 \mathrm{~cm}$ from the soil surface, with picloram solution wiped on the top one-third of the leafy spurge stems. Forage grasses were too short to be contacted by the ropewick applicators.

Treatment effectiveness through three successive, annual applications of picloram was determined by counting leafy spurge stems within two permanent $1-\mathrm{m}^{2}$ quadrats in each plot at the beginning and end of the experiment. Only stems originating from the crown or secondary roots of perennial plants were counted. In 1986 at Site 21 year after initiation of the experiment, numerous small leafy spurge seedlings were present in all plots. The butoxyethyl ester of 2,4-D at $1.1 \mathrm{~kg}$ ai $/$ ha was applied broadcast over the entire experimental area to control these seedlings 12 days after the ropewick treatments were applied.

The ending leafy spurge stem density was determined 12 months after the last herbicide treatment. Initial leafy spurge density at Site 1 ranged from 26 to $106 \mathrm{stems} / \mathrm{m}^{2}$ with a mean of 57; the range of leafy spurge stems at Site 2 was 20 to $207 / \mathrm{m}^{2}$ with a mean of 112 stems. Initial and ending leafy spurge stem counts were subjected to an analysis of covariance, and treatment means were compared using single degree of freedom contrasts.

To obtain a more reliable estimate of herbicide delivery through the ropewick applicators, separate 1.25 -ha areas near Site 2 with leafy spurge densities similar to the experimental area were treated in 1988 with the $24-$ and $80-\mathrm{g} / \mathrm{L}$ picloram solutions applied through the rigid and flexible units. The volume of herbicide solutions applied over the measured areas were used to calculate the delivery rate per hectare through the ropewick applicators as well as the delivery rate compared to the broadcast spray application. Only one large area rather than several smaller areas was treated with each solution/applicator so a measure of application variability was not established.

\footnotetext{
${ }^{3}$ Spraying Systems Co., North Ave., Wheaton, IL 60188.

${ }^{4}$ Lueschen, W. E., J. D. Purrer, and A. R. Martin. 1981. Guidelines for constructing a pipewick applicator. Nebr. Coop. Ext. Serv. NebGuide G81-555. Lincoln, NE 68583.

${ }^{5}$ Gulf Rope and Cordage Co., Box 5516, Mobile, AL 36605.
} 


\section{Results and discussion}

\section{Rigid vs. flexible applicator}

Tractor traffic by the front-end-loader-mounted ropewick applicators did not interfere with picloram activity on leafy spurge. Picloram applied through the flexible applicator controlled leafy spurge better than through the rigid ropewick at Site 1 (Table 1).

Table 1. Single degree of freedom contrast comparisons of leafy spurge stem reduction comparing two picloram solutions applied three consecutive years in one or two passes with selective ropewick applicators at two locations in northeast Nebraska, 1984 to 1988.

\begin{tabular}{|c|c|c|c|c|}
\hline \multirow[b]{3}{*}{ Contrasts } & \multicolumn{4}{|c|}{ Leafy spurge control } \\
\hline & \multicolumn{2}{|c|}{ Site 1} & \multicolumn{2}{|c|}{ Site 2} \\
\hline & Stem reduction & $\begin{array}{l}\text { Significance } \\
\text { of } F \text { values }\end{array}$ & Stem reduction & $\begin{array}{l}\text { Significance } \\
\text { of } F \text { values }\end{array}$ \\
\hline & $(\%)$ & & $(\%)$ & \\
\hline Flexible vs. rigid applicator & 68 vs. 34 & $* *$ & 78 vs. 85 & NS \\
\hline $80 \mathrm{~g} / \mathrm{L}$ vs. $24 \mathrm{~g} / \mathrm{L}$ solution & 65 vs. 38 & $* *$ & 87 vs. 77 & $* *$ \\
\hline 2 pass vs. 1 pass application & 71 vs. 32 & $* *$ & 89 vs. 75 & $* *$ \\
\hline Broadcast vs. 1 pass application & 91 vs. 32 & $* *$ & 96 vs. 75 & $* *$ \\
\hline Broadcast vs. 2 pass application & 91 vs. 71 & NS & 96 vs. 89 & NS \\
\hline Broadcast vs. $24 \mathrm{~g} / \mathrm{L}$ solution & 91 vs. 38 & $* *$ & 96 vs. 77 & $* *$ \\
\hline Broadcast vs. $80 \mathrm{~g} / \mathrm{L}$ solution & 91 vs. 65 & NS & 96 vs. 87 & $*$ \\
\hline Broadcast vs. all other treatments & 91 vs. 51 & $* *$ & 96 vs. 82 & $* *$ \\
\hline
\end{tabular}

a $* * *$ Significant at 0.05 and 0.01 probability levels, respectively; NS = not significant.

At Site 1, individual plots were laid out perpendicular to a $13 \%$ slope. With the rigid applicator, herbicide solution tended to collect in the downslope portion of the 4.6-m ropewick with some dripping from the lower compression fittings. Conversely, ropes on the upslope portion of the rigid applicator tended to dry while passing through the plot. With the flexible ropewick, individual ropes maintained constant wicking since each of the four segmented pipewick units was only $1.2 \mathrm{~m}$ long. At Site 1, if the ropewick applicators had been operated in the same direction as the pasture slope rather than across it, the advantage of the flexible applicator may have been negated.

At Site 2, leafy spurge control did not differ between the rigid and flexible ropewick applicators (Table 1). Individual plots at Site 2 were located on a wider range of slopes than at Site 1 although maximum slope was 5\%. The flexible ropewick easily traversed the undulating soil surface at Site 2; and with close operator attention, the rigid unit was positioned to apply solution on most leafy spurge stems. Considering both pasture locations, advantage in leafy spurge control was demonstrated for the flexible compared to the rigid applicator. However, on uneven terrain, it was much easier for the tractor operator to use the flexible unit with gauge wheels for height control since there was little concern for running the pipe into the soil as there was with the rigid applicator. 


\section{4- vs. 80-g/L picloram solution}

At both sites, picloram applied as the $80-\mathrm{g} / \mathrm{L}$ solution dispensed through ropewick applicators controlled leafy spurge better than did the $24-\mathrm{g} / \mathrm{L}$ solution (Table 1 ). In treating the 1.25-ha areas with the flexible and rigid applicators, an average of 0.26 and 0.40 $\mathrm{kg} / \mathrm{ha}$ picloram was applied using the $24-$ and $80-\mathrm{g} / \mathrm{L}$ solutions, respectively, or $53 \%$ more picloram dispensed using the $80-\mathrm{g} / \mathrm{L}$ solution (Table 2). Even though the $80-\mathrm{g} / \mathrm{L}$ picloram solution was $333 \%$ more concentrated than the $24-\mathrm{g} / \mathrm{L}$ solution, delivery of active picloram was only increased $153 \%$. Lueschen et al. ${ }^{6}$ found that the wicking rate of herbicide solutions decreased linearly as concentration was increased.

Control of leafy spurge with the 80 -g/L picloram solution through ropewick applicators at Site 1 did not differ from the broadcast treatment of $1.1 \mathrm{~kg} / \mathrm{ha}$ picloram (Table 1 ). The coefficient of variability was $46 \%$ at Site 1, which limited separation of treatment mean differences. At Site 2, the broadcast treatment was superior to the $80-\mathrm{g} / \mathrm{L}$ treatment.

Messersmith and Lym (9) evaluated picloram solutions of 15, 20, 30, 60, and $120 \mathrm{~g} / \mathrm{L}$ applied through a roller applicator and concluded that the $60 \mathrm{~g} / \mathrm{L}$ solution was the most economically efficient for leafy spurge control. In related research, the same series of 15to $120-\mathrm{g} / \mathrm{L}$ picloram solutions were applied through a modified pipewick applicator (1). Control with the $60-\mathrm{g} / \mathrm{L}$ picloram solution did not differ from the $120-\mathrm{g} / \mathrm{L}$ solution for 2 years after treatment.

Table 2. Estimates of the amount of picloram applied while treating leafy spurge in 1.25-ha areas with one pass of the ropewick applicator near Site 2, 1988.

\begin{tabular}{lllc}
\hline & & \multicolumn{2}{c}{ Picloram Applied } \\
\cline { 3 - 4 } Ropewick Applicator & Picloram Concentration & Rate & $\begin{array}{c}\text { Compared to } 1.1 \mathrm{~kg} / \mathrm{ha} \\
\text { broadcast rate }\end{array}$ \\
\hline & $(\mathrm{g} / \mathrm{L})$ & $(\mathrm{kg} / \mathrm{ha})$ & $(\%)$ \\
Flexible & 24 & 0.32 & 29 \\
Flexible & 80 & 0.54 & 48 \\
Rigid & 24 & 0.20 & 18 \\
Rigid & 80 & 0.26 & 23 \\
\hline
\end{tabular}

In one pass, the modified pipewick applied $22 \%$ as much picloram with a $60-\mathrm{g} / \mathrm{L}$ solution as the broadcast treatment (1). In comparison, our ropewick applicators with an 80$\mathrm{g} / \mathrm{L}$, solution applied $36 \%$ as much picloram in one pass as the broadcast treatment (Table 2). Although concern was expressed about picloram solutions plugging nylon ropes (1), decreased wicking was not apparent with the pistachio rope used in our applicators. The same ropes were used all 4 years of these experiments. The picloram (Tordon $22 \mathrm{~K}$ ) for-

\footnotetext{
${ }^{6}$ Lueschen, W. E., J. D., and A.R. 1981. Laboratory studies of factors affecting wicking rates of rope for ropewick applicators. Proc. Crop Pmt. Clinics, Neb. Coop. Ext. Serv. 177-184, Lincoln NE 68583.
} 
mulation was changed in 1983 to 1984 after discovery that aged product formed insoluble, gel-like materials in storage ${ }^{7}$.

\section{One- vs. two-pass application}

Leafy spurge control was greater at Sites 1 and 2 following application of picloram solution in two passes than when applied in one pass (Table 1). Leafy spurge control with broadcast picloram application did not differ from two-pass ropewick application at Site 1; experimental variability limited distinguishing between $91 \%$ control with broadcasting vs. $71 \%$ control with two-pass application. At Site 2, two-pass ropewick application was not different from broadcast-applying picloram.

In treating the 1.25 -ha areas, an average of $0.33 \mathrm{~kg} /$ ha picloram was applied in one pass with the ropewick applicators (Table 2). Assuming a doubling of the application rate with two passes, $40 \%$ less picloram was applied with the ropewick applicators compared to broadcast application. Regimbal et al. (12) reported a trend toward improved leafy spurge control with two vs. one-pass application of a $24-\mathrm{g} / \mathrm{L}$ picloram solution.

In regions with rolling topography, picloram applied with a flexible ropewick with gauge wheels for height control could control leafy spurge more consistently than with a rigid ropewick and with less close attention by the operator. Picloram as the $80-\mathrm{g} / \mathrm{L}$ solution controlled leafy spurge better than the $24-\mathrm{g} / \mathrm{L}$ solution, probably because $53 \%$ more picloram was dispensed (Tables 1 and 2). Leafy spurge control did not differ between picloram broadcast applied at $1.1 \mathrm{~kg} / \mathrm{ha}$ and ropewick applied as $80-\mathrm{g} / \mathrm{L}$ solution at one of two sites. Picloram applied with two passes controlled leafy spurge better than with one pass and did not differ from picloram at $1.1 \mathrm{~kg} / \mathrm{ha}$ broadcast applied while using $40 \%$ less picloram.

\section{Literature cited}

Alley, H. P., and C. G. Messersmith. 1985. Chemical control of leafy spurge. p. 65-78 in A. K. Watson, ed. Leafy Spurge. Weed Sci. Soc. Am, Champaign, IL 61820.

Bruckart, W. L., and W. M. Dowler. 1986. Evaluation of exotic rust in the United States for classical biological control of weeds. Weed Sci. 34 (Suppl. 1):11-14.

Derscheid, L. A., L. J. Wrage, and W. E. Arnold. 1985. Cultural control of leafy spurge. p. 57-64 in A. K.Watson, ed. Leafy Spurge. Weed Sci. Soc. Amer., Champaign, IL 61820.

Gylling, S. R., and W. E. Arnold. 1985. Efficacy and economics of leafy spurge (Euphorbia esula) control in pasture. Weed Sci. 33:381-385.

Harris, P., P. H. Dunn, D. Schroeder, and R. Vonmoos. 1985. Biological control of leafy spurge in North America. p. 79-92 in A. K. Watson, ed. Leafy Spurge. Weed Sci. Soc. Amer., Champaign, IL 61820.

Hickman, M. V., C. G. Messersmith, and R. G. Lym. 1989. Picloram released from leafy spurge (Euphorbia esula) roots in the field. Weed Sci. 37:167-174.

\footnotetext{
${ }^{7}$ Gast, Roger. 1989. Personal communication. Dow Chemical Co., Omaha, NE 68114.
} 
Landgraf, B. K., P. K. Fay, and K. M. Havstad. 1984. Utilization of leafy spurge (Euphorbia esula) by sheep. Weed Sci. 32:348-352.

Manners, G. D., and D. S. Galitz. 1986. Allelopathy of small everlasting (Antennaria microphylla): identification of constituents phytotoxic to leafy spurge (Euphorbia esula). Weed Sci. 34:8-12.

Messersmith, C. G., and R. G. Lym 1985. Roller application of picloram for leafy spurge control in pastures. Weed Sci. 33:258-262.

Moomaw, R. S., and A. R. Martin 1985. A flexible ropewick applicator for use on uneven terrain. Weed Sci. 33:724-726.

Rees, N. E., R. W. Pemberton, A. Rizza and P. Pecora. 1986. First recovery of Oberea erythrocephala on the leafy spurge complex in the United States. Weed Sci. 34:395-397.

Regimbal, G. A., A. R. Martin and R. S. Moomaw. 1983. Ropewick applicators with picloram in combination with chlorflurenol for leafy spurge control. Res. Rep. North Cent. Weed Control Conf. 40:54-55. 